be of value to progressive farmers as well as to students of agricultural science who will use it as a standard text.

One of its most impressive features is the masterful way that Dr. Cooke has married the lessons of the longterm classical soil fertility experiments, especially those at Rothamsted, with the results of more recent experimentation not only in Britain but also abroad. A huge volume of literature, much of it of very recent origin, has been consulted and the essential features of it have been combined under appropriate chapter headings. This has resulted in some overlapping between chapters, but the small amount of repetition is not detrimental because each chapter can be read as one of a series of complete essays. After all, it is unlikely that anyone, except a conscientious reviewer, will want to read the book from cover to cover within the space of a few days. For most it will be an authoritative book of reference to be consulted in respect of its separate parts, and good indexing adds to its value in this respect.

The book is strongest in those parts concerned with arable crop production, and this is understandable because the end products are so easily measurable in contrast with those of grassland, where there is the complication of the grazing animal as a middleman in the production process. It is not enough to talk about fertilizer responses in terms of additional grass dry matter, for one must also have some account of the value of these in terms of milk or meat. The present situation is complicated by the convention, when assessing the value of grass which is fed in association with concentrates, of making it the residuary legatee of any errors of calculation which are based on the attainment of theoretical feeding standards. Dr. Cooke cannot be blamed for this because he can do no more than make the most of available information. In doing this he has drawn attention to the considerable deficiencies of knowledge in fertilizer practice for pasture and the need for more critical methods of assessing pasture productivity.

The penultimate chapter, dealing with relationships between organic matter and soil productivity, is particularly valuable because it is such an objective analysis of knowledge on a topic which so often creates emotional rather than factual argument. It is the best balanced discussion of this subject that has been published, but this can also be said of many of the chapter headings. It is a really authoritative book and its author has just cause to be proud of it.

M. M. COOPER

\section{PRESERVATION BY IRRADIATION}

\section{Food Irradiation}

(Proceedings of the International Symposium on Food Irradiation jointly organized by the International Atomic Energy Agency and the FAO of the U.N., and held in Karlsruhe, June 6-10, 1966.) Pp. 956. (Vienna: IAEA; London: H.M.S.O., I966.) 517 schillings; I4Is. 2d.; $\$ 20 ; 80$ D.M.

THIs symposium reviewed developments in the whole field of food irradiation which have taken place since the similar meeting in 1958. The symposium was optimistic, for developments have on the whole been favourable.

The fundamental difficulties of the process of food irradiation have still not been overcome. The chief fundamental advance has been the demonstration that irradiation at temperatures below $-20^{\circ} \mathrm{C}$ reduces undesirable side effects to about one-third, which made possible the U.S. Army's plans for the sterilization of meats.

Nevertheless, the limitations are now better understood and, even accepting them, there is an already large list of potentially useful treatments. Furthermore, it is increasingly understood that feasibility must be regarded against alternative practices and, where this has been done, it seems that several irradiation processes might be economically viable. Above all, the vast American programme of feeding irradiated foods to mammals has not yielded evidence of harmful effects, other than loss of vitamins comparable with canning; and a similar smaller programme in Britain gave similar results. The U.S. and Canadian authorities have permitted irradiation of particular foods, with more in prospect; and legislators in other countries are actively considering how to deal with the situation. While there have been substantial international exchanges, such as this symposium, where uniformity of view on technical matters has been sought, the conference noted the lack of similar attempts on the legislative plane, though this seems necessary to facilitate potential international trading in irradiated foods.

Several outstanding points of technical difficulty are evident in these proceedings, besides the obvious need to diminish the side effects and increase the microbicidal power of irradiation. These difficulties are the especially poor control by irradiation of viruses and enzymes; the significance of conceivable mutations in micro-organisms causing food poisoning; the discrepancy betweer the toxic effects of irradiated nutrients on single cells and the absence of corresponding effects in animal feeding trials; and the difficulty of detecting whether a food has been irradiated. The general impression is, however, that many possible processes would not be seriously affected by these difficulties, and that applications are likely in many countries as soon as the laws are regularized.

M. Ingram

\section{EARLY PREGNANCY}

\section{Pre-implantation Stages of Pregnancy}

Edited by G. E. W. Wolstenholme and Maeve O'Connor. (Ciba Foundation Symposium.) Pp. xii +430 . (London: J. and A. Churchill, Ltd., 1965.) $65 s$.

THIs book is an account of the proceedings of one of the many small international conferences on a variety of topics of biological and medical research, which have been convened by the Ciba Foundation. This particular symposium was held in April 1965, under the distinguished chairmanship of Professor C. H. Waddington, and the resulting volume contains sixteen contributions on many different aspects of the pre-implantation stages of mammalian development.

The first two papers deal with the ultrastructural changes which occur in the egg during fertilization, and with the fine structure of the blastocysts of selected mammalian species. Others deal with energy metabolism, nucleic acid and protein synthesis, genetic aspects and the influence of various maternal factors on early embryonic development.

The short discussions which follow each paper that was read and the more extensive general discussions are quite as interesting as the papers themselves, and contribute substantially to the value of this interesting book.

B. MORRIS

\section{OBITUARIES}

\section{Professor J. W. Heslop Harrison}

Professor John William Heslop Harrison died at his home in Birtley, Co. Durham, on January 23, 1967, the day after his eighty-sixth birthday. Harrison was emeritus professor of botany of the Universities of both Durham and Newcastle upon Tyne.

He received his early education at Rutherford College, Newcastle upon Tyne, and in 1903 graduated B.Sc. from 